\title{
Histomorphology of Vomeronasal Organ in Scincella tsinlingensis
}

\author{
Histomorfología del Órgano Vomeronasal en Scincella tsinlingensis
}

Chun Yang; Zhaoting Kou; Lin Li; Yanyan Gao \& Zhiwei Gong

YANG, C.; KOU, Z.; LI, L.; GAO, Y. \& GONG, Z. Histomorphology of vomeronasal organ in Scincella tsinlingensis. Int. J. Morphol., 38(3):602-610, 2020.

SUMMARY: Due to the great change in the morphology of squamate vomeronasal organ (VNO), the histomorphology characteristics of VNO in Scincella tsinlingensis were studied by light and electronic microscopy. The results indicated that the VNO of S. tsinlingensis was located at the base of nasal cavity and consisted of a mushroom body situated anteroventrally and a sensory epithelium (SE) situated dorsocaudally. SE was composed of supporting cells, receptor cells and basal cells, and the supporting cells contained secretory granules near the surface membrane. Most of receptor cells were irregular in shape with long cytoplasmic extensions and characterized by microtubules, vesicles, and mitochondria. The basal cells with long cytoplasmic extensions were also irregular in shape and appeared a greater electron density than others. The thick nerve bundles were found on the dorsomedial area of VNO, and the surface of mushroom body was non-sensory epithelium consisting of ciliated and basal cells, without goblet cells. Epithelial cells were arranged in irregular, with many cilia and microvilli distributed on its free surface. Cells on the basal layer were irregularly circular in shape and arranged sparsely. Taken together, the results indicated that the fine structure of VNO in S. tsinlingensis was similar to other species from scincomorphs.

KEY WORDS: Scincella tsinlingensis; Vomeronasal organ; Histomorphology.

\section{INTRODUCTION}

Most vertebrates have nasal olfactory system (NOS) and vomeronasal system (VNS) (Shipley et al., 1995; Grus \& Zhang, 2006). The former almost exists in all vertebrate species, with stable evolution of vertebrates, while the latter is composed of a peripheral organ and the connected central neuronal networks (Aland et al., 2016), which is firstly appeared in amphibians (Eisthen, 1997) other than some Caudata amphibians, e.g., Andrias davidianus (Zhang et al., 1991). The NOS is specialized for small and volatile chemicals that easily diffuse into the air and travel over long distances. On the contrary, VNS is often specialized for the reception of nonvolatile chemicals with high molecular weight (Filoramo \& Schwenk, 2009). The vomeronasal organ (VNO) may be derived from the recess epithelium or fishtype olfactory epithelium, which can be differentiated into the mammal-type VNO and snake-type VNO (Taniguchi \& Taniguchi, 2014). In most tetrapods, the paired and blindending tubes are observed in ventral nasal septum (Saito et al., 2003; Aland et al.), which plays pivotal roles in interindividual interactions and environmental recognition (Brykczynska et al., 2013). However, this is absent in fishes and birds.
The extensive changes in VNO structure has led to speculation on how to use the size and structure for infer function. Reptiles constitute the paraphyletic group in taxonomy without common ancestors in phylogeny, and the development of VNO is also different among reptilian species (Taniguchi \& Taniguchi). The organ is not found in crocodiles and chameleons, but present in some other reptiles and may be even larger than the olfactory organ (Døving $\&$ Trotier, 1998). VNO is able to receive some non-volatile organic molecules in the air as an important chemical sensor in reptiles, for example, pheromone, and will affects ingestion, identification, predator avoidance and breeding behavior (Graves et al., 1991; Placyk Jr. \& Graves, 2002). The origin and details of these differences are still unknown, and it is necessary to examine the $\mathrm{VNO}$ of various species first.

The morphology of the squamate VNO has changed considerably, and it is believed that detailed structural examinations of various squamous species are needed to elucidate the evolution of chemoreception in squamate reptiles (Schwenk, 1993). Phylogenetically classified as a member of the family Scincidae and order to Squamata, 
Scincella tsinlingensis also belongs to ovoviviparous lizard (Yang et al., 2016). S. tsinlingensis, an endemic species in China, is widely distributed in Gansu, Shaanxi, Shanxi province, and lives on a sunny slope with an altitude of $900-$ $1800 \mathrm{~m}$, and preys on small insects. Recorded by "Lists of terrestrial wildlife under state protection, $S$. tsinlingensis are beneficial or of important economic or scientific value". Contemporary research on $S$. tsinlingensis mainly focuses on its excretory system and digestive system (Wang et al., 2016). What's more, the microstructure and ultrastructure of VNO investigated in the lizard maybe useful in elucidating the evolution of chemoreception in squamates.

\section{MATERIAL AND METHOD}

Twelve healthy specimens of adult $S$. tsinlingensis (6 males, 6 females) were collected from Qiliyu forest region in Taiyue Mountain, Shanxi, China $\left(36^{\circ} 21^{\prime}-36^{\circ} 45^{\prime} \mathrm{N}\right.$, $\left.110^{\circ} 40^{\prime}-112^{\circ} 21^{\prime} \mathrm{E}\right)$. The lizards studied had similar weight $(2.73 \pm 0.45)$ and snout vent length $(98.36 \pm 11.58)$. After deep anaesthetization with ether, the animals were killed by decapitation, with anterior maxillas immediately removed.

Light microscopy. Four anterior maxillas samples (2 males, 2 females) for light microscopy were fixed 3-5days with Bousin's solution. All samples were dehydrated in a graded series of ethanol, penetrated with xylene, paraffinembedding, and serial slices in $8 \mathrm{~mm}$, and stained with hematoxylin-eosin (H.E). Finally, we observed them in sections and collected images under Olympus BX51 digital imaging system (Olympus, Tokyo).

Scanning electron microscopy. Four pairs of VNO samples (2 males, 2 females) were fixed overnight at $4{ }^{\circ} \mathrm{C}$ with $2.5 \%$ glutaraldehyde solution (PH 7.4) for scanning electron microscopy, transferred to phosphate buffer $(0.1 \mathrm{M}, \mathrm{PH} 7.4)$ for rinsing, and dehydrated in a graded series of ethanol, critical point drying with $\mathrm{CO}_{2}$, sputter-coating with palladium ions. At last, the specimens were observed with JSM-7500F scanning electron microscope (JEOL, Tokyo), and photographed at $15 \mathrm{kV}$.

Transmission electron microscopy. Four pairs of VNO samples ( 2 males, 2 females) were dissected for transmission electron microscopy, and fixed overnight at $4{ }^{\circ} \mathrm{C}$ with $2.5 \%$ glutaraldehyde solution. After rinsing in $0.1 \mathrm{M}$ phosphate buffer (PH 7.4), samples were post-fixed in $1 \%$ osmium tetroxide for $1 \mathrm{~h}$. All samples were dehydrated in a graded series of acetone, embedded in Epon 812 epoxy resin, cut into ultrathin sections, and double stained with uranyl acetate-lead citrate. In the end, these sections were observed with H-760 transmission electron microscope (Hitachi, Tokyo) and photographed at $80 \mathrm{kV}$.

\section{RESULTS}

Light microscopy of VNO. The consecutive cross-sections of $S$. tsinlingensis maxilla stained with H.E indicated that VNO was paired and symmetrical dome-shaped structure wrapped in a bony capsule and separated by nasal septum cartilage (Fig. 1-A, B,C). Located at the base of nasal cavity, the organ was consisted of a mushroom body situated anteroventrally and a sensory epithelium (SE) situated dorsocaudally (Fig. 1-B). The above two structures were located on opposite sides of narrow vomeronasal lumen, rostrally communicating with the buccal cavity through a narrow vomeronasal duct opening dorsally on the palate (Fig. 1-B), i.e., the vomeronasal fenestra, anterior to the choana (Fig. 1-C). The diameter of mushroom body was about 270 $\mu \mathrm{m}$. There are no glands under the SE, and the supporting cells were not secretory. The thick nerve bundles formed by VNO receptor cells lied in the dorsomedial region of VNO (Fig. 1-G). In the back of VNO, both sides of the nasal septum, large olfactory nerve bundles ran under the olfactory epithelium (Fig. 1-D).

The roof and sides of the dome of vomeronasal organ were lined with SE, and the thickest part of VNO SE was the medial aspect, which was about $125 \mu \mathrm{m}$ and might be stacked with 20 nuclei from base to surface (Fig. 1-B,G). The free surface of SE ends in a fine brush without cilia (Fig. 1-G). The SE was composed of supporting cells, microvillous bipolar receptor cells and basal cells. A large number of receptor cells occupied the most areas of SE. Under the optical microscope, the dividing line among three types of cells could not be clearly distinguished. However, capillaries have been occasionally observed (Fig. 1-I, F).

There are no goblet cells in non-sensory epithelium (NSE) over the mushroom body, and the luminal surface of mushroom body was covered with ciliated columnar epithelium, which was about $25 \mu \mathrm{m}$ thick and lower than its sensory counterpart (Fig. 1-E, H). Besides, the arrangement of epithelial cells was irregular. More concentrated and round nuclei of sparse basal cells were above the basal lamina. The lamina propria contained blood vessels, nerve fibers and connective tissue and the occasional mast cell, and the central core of mushroom body was capped with cartilage cells (Fig. 1-D).

Scanning electron microscopy of VNO. A great number of microvilli were found on the apical surface of lizard 

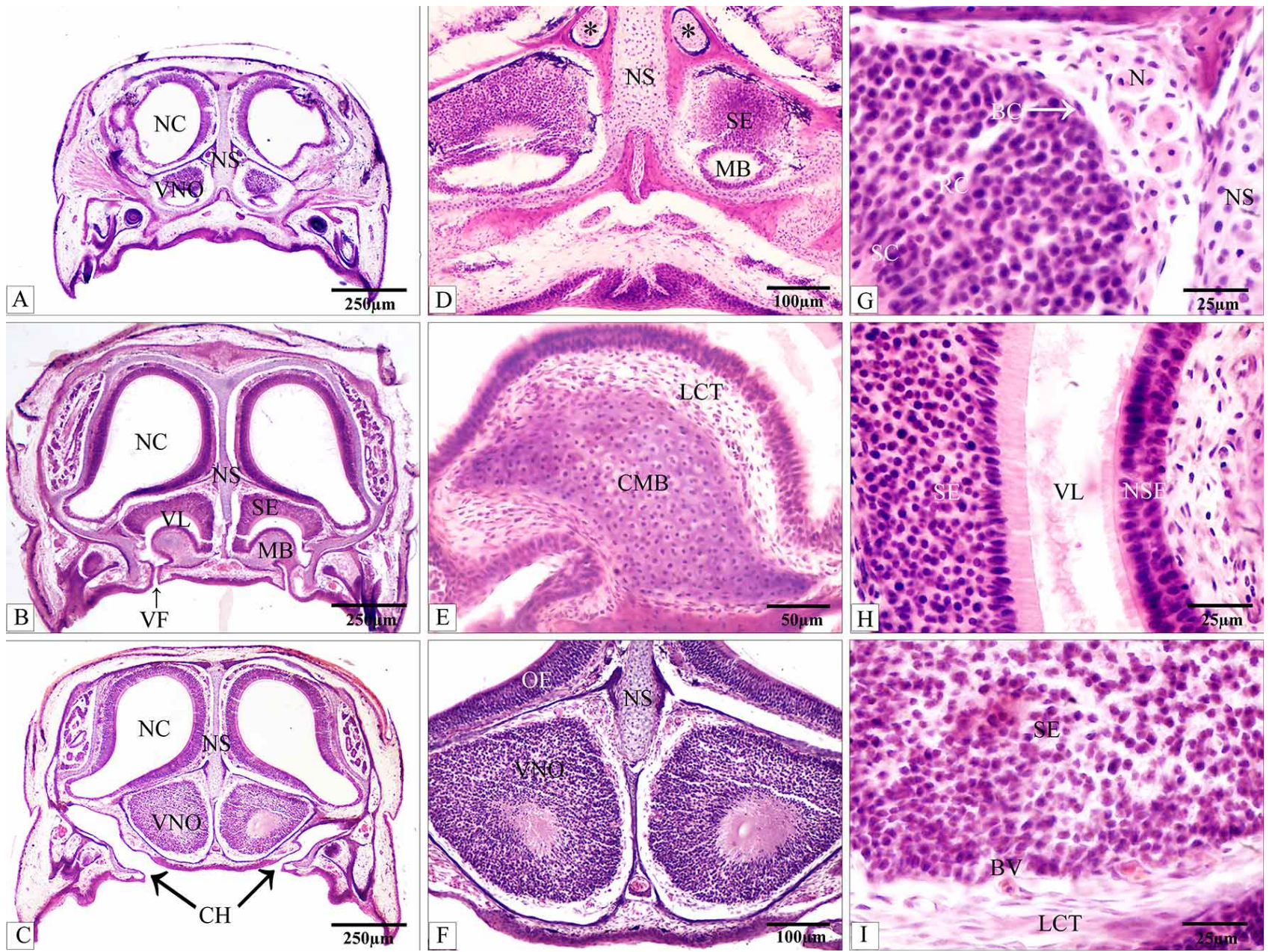

Fig. 1. Histological features of the VNO and nasal cavity in S. tsinlingensis. (A,B,C). Light micrograph of coronal section of VNO show front, middle and rear parts of the VNO. (D)*Large olfactory nerve bundles running beneath the olfactory epithelium. (E) The MB covered with NSE, and its free surface lined with orderly short brush margin. Cartilage of the mushroom body (CMB) distributed with cartilage cells (CC). (F) Light micrograph of rear section of VNO showing areas of olfactory and vomeronasal epithelium. (G) The thick nerve bundles were observed on the dorsomedial region of VNO. (H, I) Histological structures of SE and NSE. The vomeronasal lumen (VL) covered with thick SE consisted of supporting cells (SC), receptor cells (RC) and basal cells (BC). NS: nasal septum; CH:choanae; OE:olfactory epithelium; NC: nasal cavity; BV: blood vessels; LCT: loose connective tissue;VF: vomeronasal fenestra; OE:olfactory epithelium.

sensory epithelial cells, which are approximately 100 to 150 $\mathrm{nm}$ in diameter and 2 to $3 \mathrm{~mm}$ in length. The microvilli are derived from the projections of supporting cells (Fig. 2). No differences in size and surface morphology of microvilli between two cell types were observed by the scanning electron microscopic.

In contrast to SE, the luminal surface of NSE was covered with numerous cilia. Cilia of mushroom body's nonsensory epithelial cells projected into the lumen of vomeronasal organ. In other areas, the cilia pressed against the cell surface. In addition, there were also regularly arranged NSE cells on the fracture surface of mushroom body (Fig. 3).
Transmission electron microscopy of VNO. Most cytoplasm of supporting cells was above the nucleus and narrow to thin. The elongate nuclei appeared irregularly oval in shape. There was a small amount of mitochondria in cytoplasm, with many smooth endoplasmic reticulum around the nuclear and secretory granules near the surface membrane. Irregularly shaped vesicles were observed in cytoplasm of supporting cells above the nucleus. Moreover, bundles of fine fibrillar material appeared in the basal part of supporting cell, closely similar as those seen in the basal cells. It is difficult to distinguish the microvillous projections on supporting cells from the thin terminal part of sensory microvilli. 

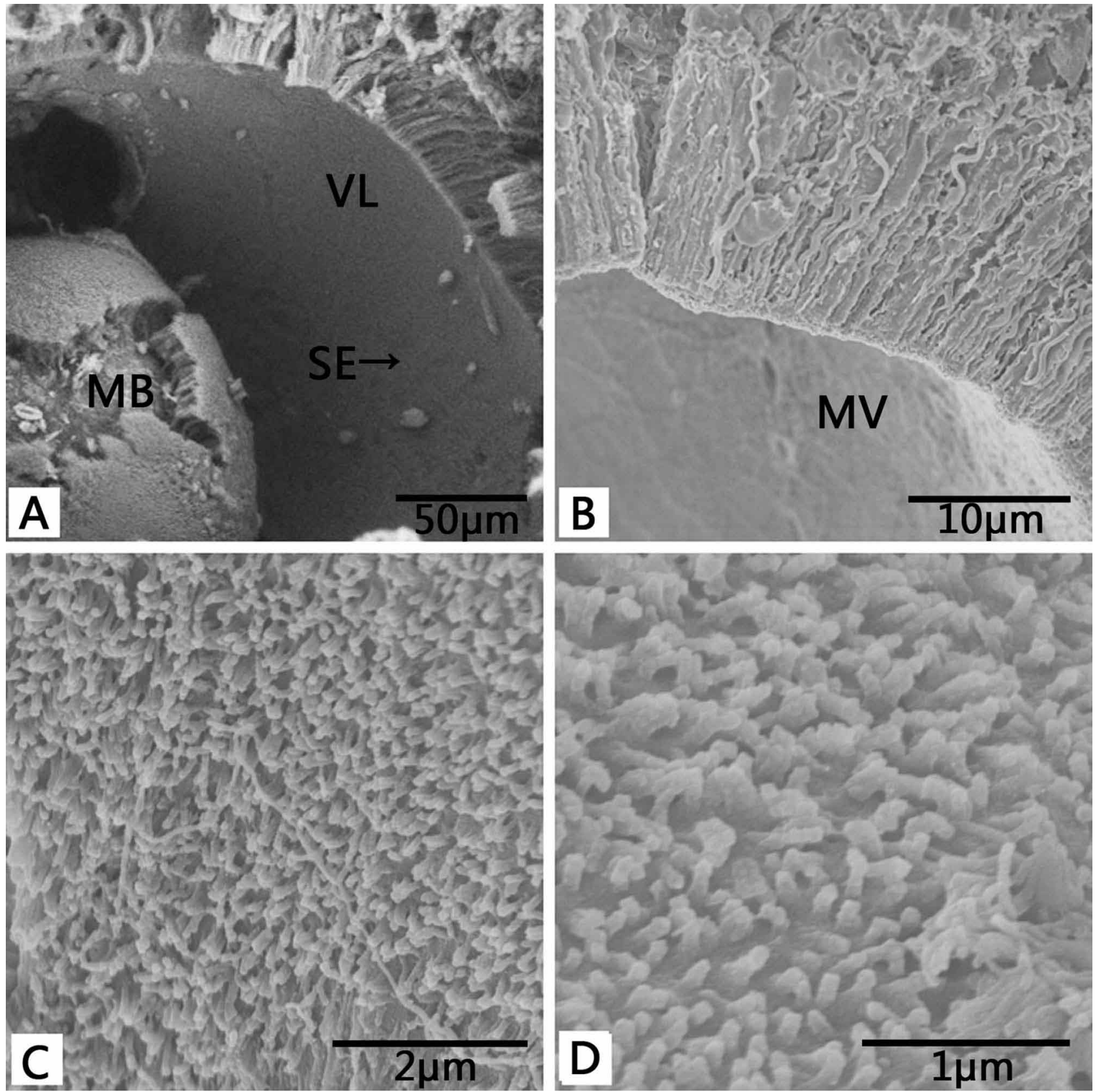

Fig. 2. Scanning electron micrograph of the vomeronasal sensory epithelium. (A) The VNO consisted of vomeronasal lumen (VL) and mushroom body (MB), and the sensory epithelium (SE) on the surface of vomeronasal lumen. (B) On the free surface of sensory epithelium distributed with dense microvilli (MV). (C) The dense microvilli. (D) Image showed the microvilli at higher magnification.

Many receptor cells were irregular in shape with long cytoplasmic extensions and characterized by microtubules, vesicles, and mitochondria. The nucleus appeared irregularly round in shape, which were obvious with well-developed heterochromatin. A great number of organelles with well-developed smooth endoplasmic reticulum and a small amount of Golgi apparatus and free ribosomes were observed around the nuclear. There were also many vesicles distributed in the cytoplasm near the surface membrane, and many microfilaments ran longitudinally in the microvillus (Fig. 4-A).

Relatively more perinuclear cytoplasm with nucleus rounder and smaller than more basally situated cells were found in the cells above the basal lamina. Additionally, the large, oval and irregularly shaped nuclei occupying 

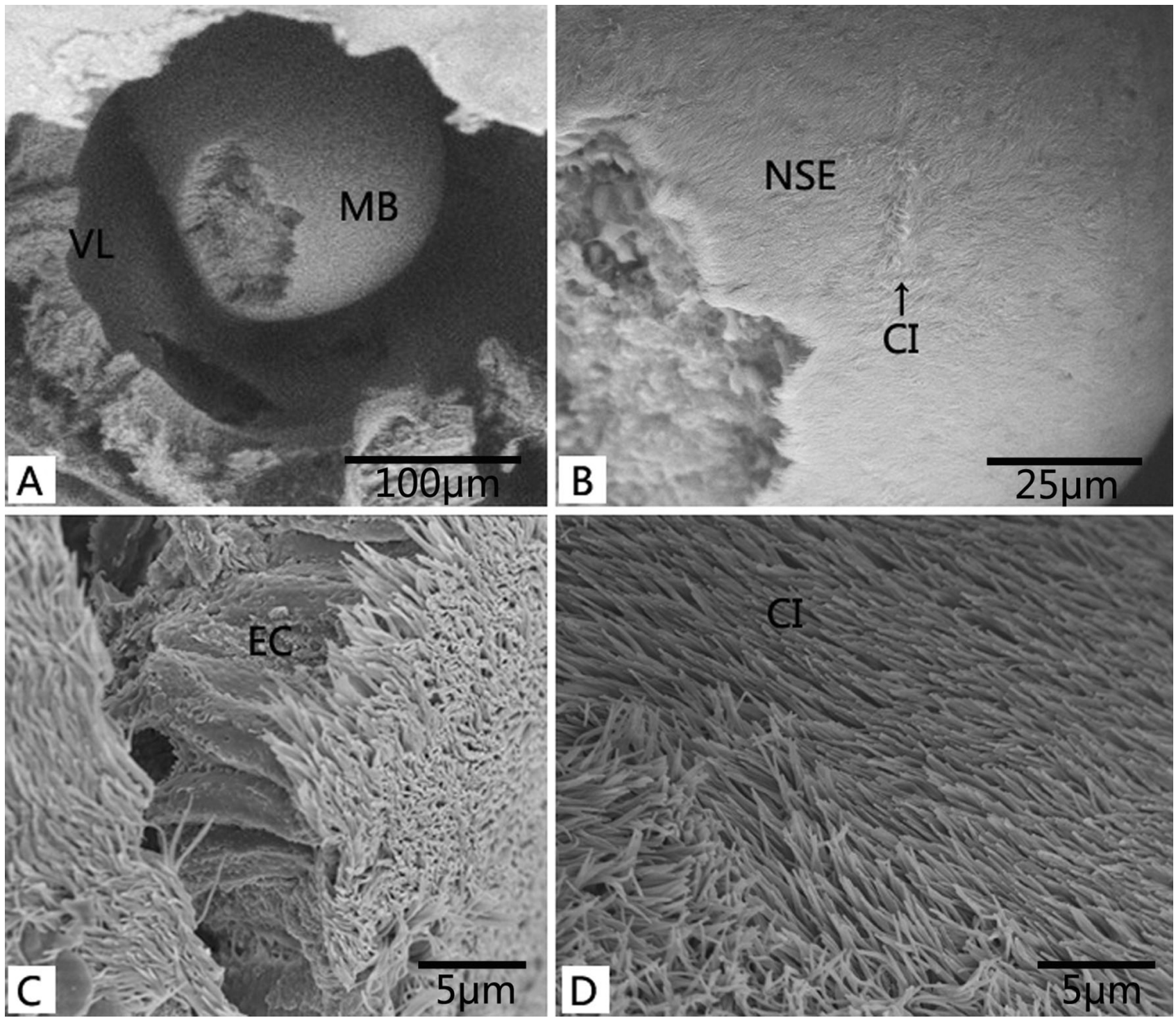

Fig. 3. Scanning electron micrograph of vomeronasal NSE. (A) The VNO consisted of vomeronasal lumen (VL) and mushroom body (MB). (B) The NSE covered in the surface of mushroom body, showed the dense cilia (CI). (C) The fracture plane of mushroom body showed the regular arranged NSE cells (EC). (D) Image at higher magnification showed the dense cilia (CI) covered on the surface of NSE.

almost the entire cell body were contained in some undifferentiated cells (Fig. 4-C). Usually, basal cells were orientated with the long axis of nucleus parallel to the basal lamina. The basal cells with long cytoplasmic extensions were irregular in shape with greater electron density than others. Their cytoplasmic processes went up between receptor cells (Fig. 4-D).

Composed of ciliated non-sensory epithelial cells, the NSE had many cilia and microvilli on its free surface. The cilia were about $5 \mu \mathrm{m}$ in length, and equipped with basal bodies at base. The diameter of microvilli was about $2 \mu \mathrm{m}$ (Fig. 5-A). Some secretory vacuoles were interspersed among non-sensory epithelial cells (Fig. 5-B). The cytoplasm near its free surface contained a large number of mitochondrion, with few smooth endoplasmic reticulum and Golgi apparatus around the nuclear. Basal cells were relatively small, irregularly circular in shape and sparsely arranged (Fig. 5-C). There was a small amount of mitochondria, smooth endoplasmic reticulum and Golgi apparatus in the cytoplasm of these cells. Besides, cartilage cells were also found in the mushroom body (Fig. 5-D). 

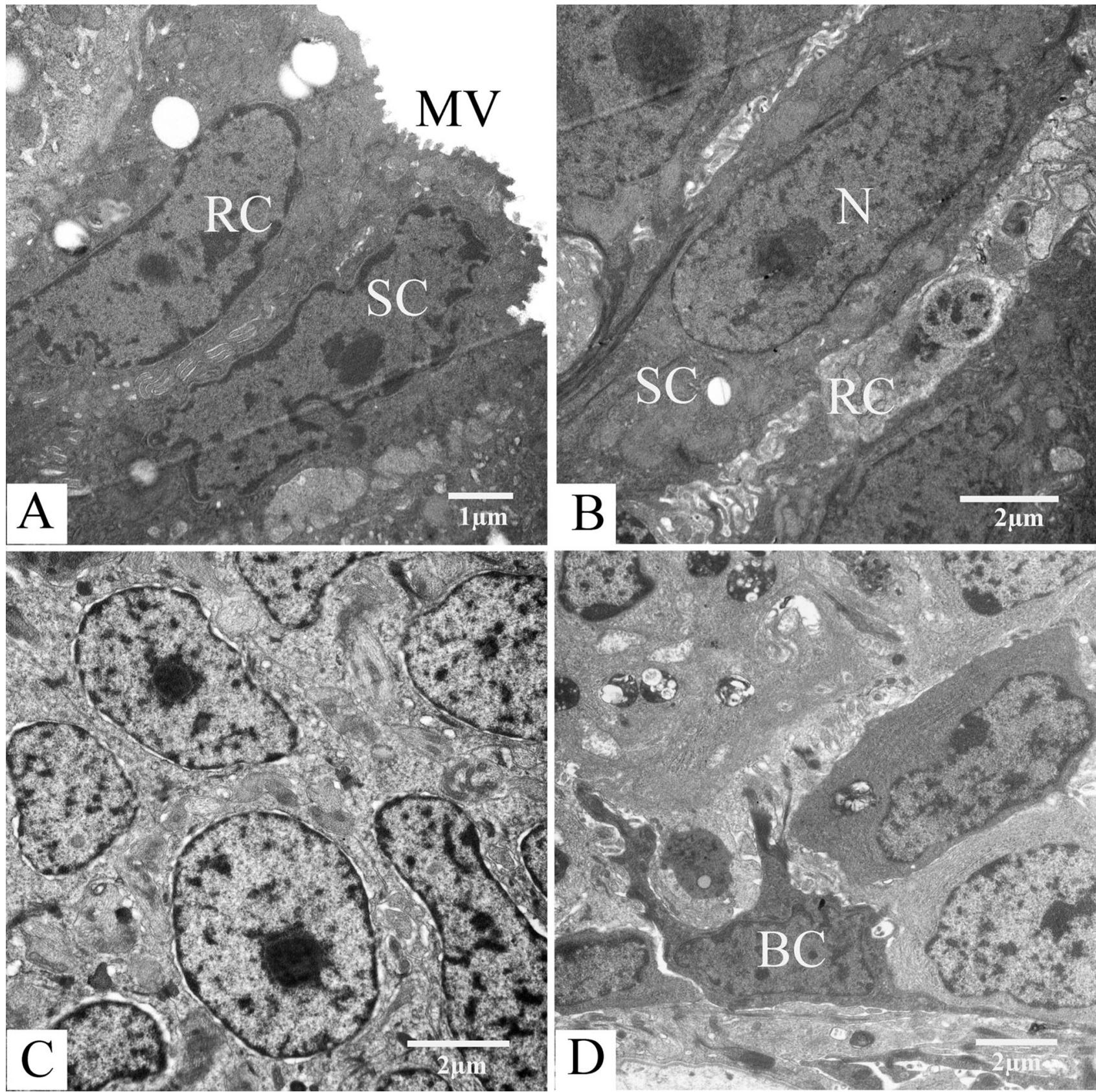

Fig. 4. Transmission electron micrograph of the vomeronasal SE. (A) The free surfaces of supporting cells (SC) were covered with microvilli (MV), and receptor cells (RC) were covered with cilia (CI). (B) Receptor cell dendrites can be distinguished between the supporting cells. (C) Above the basal lamina, some undifferentiated cells contained large, oval and irregularly shaped nuclei occupying almost the entire cell body.(D) Electron-dense basal cells(BC) send off processes between sensory cells.

\section{DISCUSSION}

The VNS consisted of vomeronasal organ (VNO), accessory olfactory bulb, amygdala and nerves connected with each other (Changnam Park et al., 2013), affected ingestion, identification, predator avoidance, breeding and predation behavior (Graves et al., 1991; Placyk Jr. \& Graves).The VNO, also called as the Jacobson's organ, was a complex organ playing critical roles in many behavioral aspects and existed in many vertebrate species. Different 


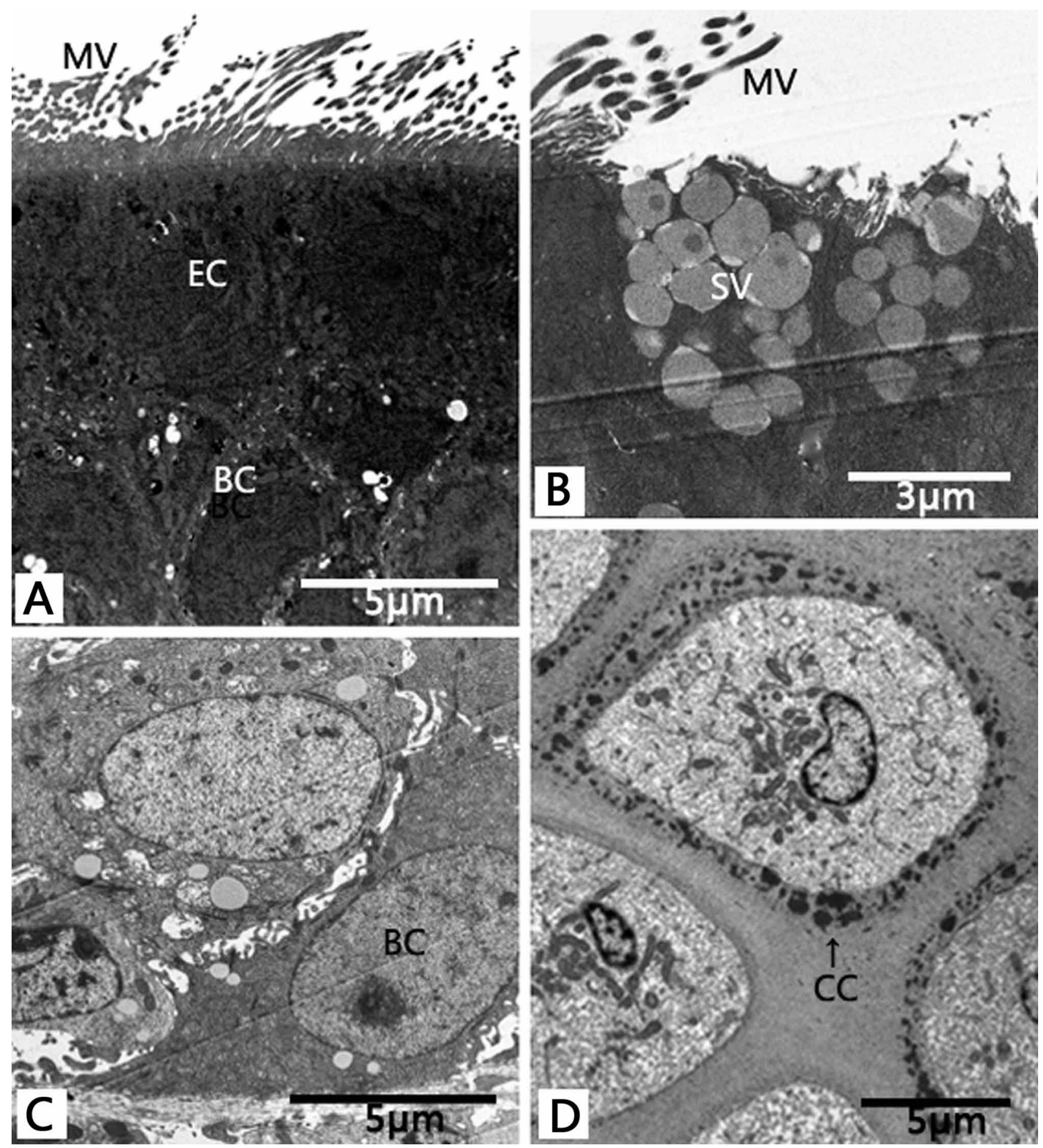

Fig. 5. Transmission electron micrograph of the vomeronasal NSE. (A) NSE consisted of epithelial cells (EC) and basal cells (BC), showing microvilli (MV). (B) Among non-sensory epithelial cells interspersed some secretory vacuoles (SV). (C) Basal cells (BC) were irregularly circular in shape and sparsely arranged. (D) The inside of mushroom body distributed with cartilage cells (CC).

from other vertebrates, the paired VNOs of squamates have lost their anatomical connection to the main olfactory system completely, serving as autonomous chemosensory organs (Baeckens et al., 2017).
The fine structure of squamate VNO can differ from one species to another. Three types of cells, receptor cells, supporting cells and basal cells, were existed in NSE of VNO, for example, Lacerta sicula, Natrix natrix (Altner et al., 
1970), Takydromus tachydromoides (Saito et al., 2010) and S. tsinlingensis. However, basal cells (or undifferentiated cells) were lacked in the mouse vomeronasal organ along the base of bipolar cell layer. In a wide variety of terrestrial vertebrates, cilia was not existed in vomeronasal receptor cells. Instead, microvilli was available in the receptor cell terminals in vomeronasal epithelium which were supported by the SEM observations in S. tsinlingensis. The presence or absence of cilia on chemoreceptor cells may be connected with the physical conditions on cell surface (Kratzing, 1975). This difference seems to be a general feature to distinguish two epithelia, which may be connected with the differential role of these two chemosensory systems in many animal behaviors (Wang \& Halpern, 1980). One of the most characteristic features of the SE of VNO in snakes was the presence of columnar compartments with bipolar neurons (Wang \& Halpern; Takami \& Hirosawa, 1990). No similar structure was observed in lizard, including $S$. tsinlingensis. An unusual feature of lizard Tiliqua scincoides scincoides was the intrusion of columns of connective tissue carrying blood vessels to the epithelial surface. On both sides of columns, there were bundles of nerve fibres, which were the proximal extensions of sensory cells (Kratzing).

The VNO of snakes and lizards, except for chameleons, was well developed and contained the SE of dorsal dome and NSE lined the ventral concha, which was called the mushroom body (Kaczmarek et al., 2017). The movement mechanism of chemicals through the vomeronasal fenestrae and into the lumen of VNO was related to the mushroom body. The NSE on mushroom body in $S$. tsinlingensis was similar to that of several species of snakes and lizards (Saito et al., 2010), which consisted of ciliated and basal cells. Different from T. tachydromoides, there was no novel non-ciliated cell, which had constricted apical cytoplasm and microvilli instead of cilia and were sparsely distributed in the epithelium. Scincidae was divided into two subfamilies, Galliwasp and Skink. At present, these cells were only found in Galliwasp. However, it was still required for further comparative studies in other species of Galliwasp and Skink no matter whether it was a unique feature of Galliwasp (Saito et al., 2010). One common feature of scincomorphs was the distribution of secretory granules in VNO, which may distinguish them from other squamate taxa (Rehorek et al., 2000). Secretory granules have been reported in the supporting cells of VSE in L. sicula, which belonged to Lacertidae (Altner et al.). Some secretory vacuoles were interspersed among then on-sensory epithelial cells of mushroom body in S. tsinlingensis, as described in Tiliqua scincoides, which belonged to Scincidae (Kratzing). The centrioles in the VNO receptor cells of squamate reptiles were quite different (Saito et al., 2010). According to the vertebrates examined, one species of burrowing lizard,
Anguis fragilis (Bannister, 1968), and scincomorph lacertid L. sicula (Altner et al.) lacked centrioles in the VNO receptor neurons.

This indicated that, VNO was directly caused by the adaptation to the terrestrial life, and the VNO of $S$. tsinlingensis seems essentially similar to that in Squamate reptiles (Brykczynska et al.). Their VNO thoroughly separated from the $\mathrm{NC}$, and further formed an independent and well-developed sensory organ, which independently opened to the oral cavity through the vomeronasal fenestra in palate. It can be seen from the study that, there was a strong adaptability of $S$. tsinlingensis to the terrestrial environment, and the tongue delivered chemicals close to or into the vomeronasal openings. Subsequently, the molecules passed through the vomeronasal duct into VNO's lumen where they dissolved in the luminal fuid. The presence of molecules in the fuid was detected by SE. Finally, the stimulated SE relayed information from the accessory olfactory nerves to the accessory olfactory bulbs of telencephalon for treatment (Baeckens et al.). Due to the lack of relevant glands to produce liquid, such as vomeronasal gland, the VNO of reptiles could not secrete mucus to wet the vomeronasal lumen. Studies suggested that salivary glands in oral or Harderian glands around the eyes in some reptiles could secrete mucus. The mucus entered the vomeronasal lumen through vomeronasal or nasolacrimal duct, which effectively offset the lack of vomeronasal gland, and was conducive to the reptiles terrestrial life. In addition, the non-sensory epithelial surface of $S$. tsinlingensis $\mathrm{VNO}$ were covered with dense cilia. Based on the relevant reports, the cilia movement was able to promote the mixture and spread of smell factor in narrow vomeronasal lumen, which was significant to live in the land of Squamate (Saito et al., 2010).

In conclusion, the fine structure of VNO in $S$. tsinlingensis was similar to other species from scincomorphs. Our descriptions are very useful for future comparative studies of Squamata, both at their anatomical and histological levels. However, the ultrastructure of VNO was still unclear in many other reptiles. Therefore, further studies on the structure of VNS and VNO of these reptile species may help elucidate the chemosensory evolution of Squamates.

\section{ACKNOWLEDGEMENTS}

This study received financial supports from the Scientific Research Foundation for Doctors of Shanxi Normal University (No.833174) and National Training Programs of Innovation and Entrepreneurship for Undergraduates (No.201510118001). 
YANG, C.; KOU, Z.; LI, L.; GAO, Y. \& GONG, Z. Histomorfología del organo vomeronasal en Scincella tsinlingensis. Int. J. Morphol., 38(3):602-610, 2020.

RESUMEN: Debido al gran cambio en la morfología del órgano vomeronasal $(\mathrm{OVN})$, se estudiaron las características histomorfológicas en la Scincella tsinlingensis por microscopías de luz y electrónica. Los resultados indicaron que el OVN de $S$. tsinlingensis se localizaba en la base de la cavidad nasal y consistía en un cuerpo como hongo situado anteroventralmente y un epitelio sensorial (ES) situado dorso caudamente. El ES estaba compuesto de células de soporte, células receptoras y células basales, y las células de soporte contenían gránulos secretores cerca de la membrana superficial. En gran parte de la mayoría de las células receptoras se observó una forma irregular con largas extensiones citoplasmáticas, caracterizadas por microtúbulos, vesículas y mitocondrias. Las células basales con extensiones citoplasmáticas también tenían forma irregular y algunas parecían tener una mayor densidad de electrones. Los haces gruesos nerviosos se encontraron en el área dorsomedial del OVN, la superficie del cuerpo de estaba compuesto de epitelio no sensorial y consistía de células ciliadas y basales, sin células caliciformes. Las células epiteliales estaban dispuestas de manera irregular, con muchos cilios y microvellosidades distribuidas en su superficie libre. Las células en la capa basal eran escasas y de forma circular irregular. Tomados en conjunto, los resultados indicaron que la estructura fina del OVN en S. tsinlingensis era similar a otras especies de scincomorpha.

PALABRAS CLAVE: Scincella tsinlingensis; Órgano vomeronasal ; Histomorfología.

\section{REFERENCES}

Aland, R. C.; Gosden, E. \& Bradley, A. J. Seasonal morphometry of the vomeronasal organ in the marsupial mouse, Antechinus subtropicus. J. Morphol., 277(11):1517-30, 2016.

Altner, H.; Müller, W. \& Brachner, I. The ultrastructure of the vomeronasal organ in reptilian. Z. Zellforsch. Mikrosk. Anat., 105(1):107-22, 1970.

Baeckens, S.; Herrel, A.; Broeckhoven, C.; Vasilopoulou-Kampitsi, M.; Huyghe, K.; Goyens, J. \& Van Damme, R. Evolutionary morphology of the lizard chemosensory system. Sci. Rep., 7(1):10141, 2017.

Bannister, L. H. Fine structure of the sensory endings in the vomero-nasal organ of the slow-worm Anguis fragilis. Nature, 217:275-6, 1968.

Brykczynska, U.; Tzika, A. C.; Rodriguez, I. \& Milinkovitch, M. C. Contrasted evolution of the vomeronasal receptor repertoires in mammals and squamate reptiles. Genome Biol. Evol., 5(2):389-401, 2013 .

Døving, K. B. \& Trotier, D. Structure and function of the vomeronasal organ. J. Exp. Biol., 201(Pt. 21):2913-25, 1998.

Eisthen, H. L. Evolution of vertebrate olfactory systems. Brain Behav. Evol., 50(4):222-33, 1997.

Filoramo, N. I. \& Schwenk, K. The mechanism of chemical delivery to the vomeronasal organs in squamate reptiles: a comparative morphological approach. J. Exp. Zool. A Ecol. Genet. Physiol., 311(1):20-34, 2009.

Graves, B. M.; Halpern, M. \& Friesen, J. L. Snake aggregation pheromones: source and chemosensory mediation in western ribbon sankes (Thamnophis proximus). J. Comp. Psychol., 105(2):140-4, 1991.
Grus, W. E. \& Zhang, J. Origin and evolution of the vertebrate vomeronasal system viewed through system-specific genes. Bioessays., 28(7):709$18,2006$.

Kaczmarek, P.; Hermyt, M. \& Rupik, W. Embryology of the VNO and associated structures in the grass snake Natrix natrix (Squamata: Naticinae): A 3D perspective. Front. Zool., 14:1, 2017.

Kratzing, J. E. The fine structure of the olfactory and vomeronasal organs of a lizard (Tiliqua scincoides scincoides). Cell Tissue Res., 156(2):239$52,1975$.

Placyk Jr., J. S. \& Graves, B. M. Prey detection by vomeronasal chemoreception in a plethodontid salamander. J. Chem. Ecol., 28(5):1017-36, 2002.

Rehorek, S. J.; Firth, B. T. \& Hutchinson, M. N. The structure of the nasal chemosensory system in squamate reptiles. 2 . Lubricatory capacity of the vomeronasal organ. J. Biosci., 25(2):181-90, 2000.

Saito, S.; Matsui, T.; Kobayashi, N.; Wakisaka, H.; Mominoki, K.; Matsuda, S. \& Taniguchi, K. Lectin histochemical study on the olfactory organ of the newt, Cynops pyrrhogaster, revealed heterogeneous mucous environments in a single nasal cavity. Anat. Embryol. (Berl.), 206(5):349-56, 2003.

Saito, S.; Oikawa, T.; Taniguchi, K. \& Taniguchi, K. Fine structure of the vomeronasal organ in the grass lizard, Takydromus tachydromoides. Tissue Cell, 42(5):322-7, 2010.

Schwenk, K. The evolution of chemoreception in squamates reptiles: a phylogenetic approach. Brain Behav. Evol., 41(3-5):124-37, 1993.

Shipley, M.; McLean, J. \& Ennis, M. Olfactory System. The Rat Nervous System. $2^{\text {nd }}$ ed. San Diego, Academic Press, 1995. pp.899-926.

Takami, S. \& Hirosawa, K. Electron microscopic observations on the vomeronasal sensory epithelium of a crotaline snake, Trimeresurus flavoviridis. J. Morphol., 205(1):45-61, 1990.

Taniguchi, K. \& Taniguchi, K. Phylogenic studies on the olfactory system in vertebrates. J. Vet. Med. Sci., 76(6):781-8, 2014.

Wang, L. M.; Yang, C. \& Guo, L. Observation on histology of digestive system and argyrophil cells in digestive tube of Tsinling dwarf skink, Scincella tsinlingensis. Chin. J. Zool., 51(4):614-22, 2016.

Wang, R. T. \& Halpern, M. Light and electron microscopic observations on the normal structure of the vomeronasal organ of garter snakes. $J$. Morphol., 164(1):47-67, 1980.

Yang, C. \& Wang, L. Histological and morphological observations on tongue of Scincella tsinlingensis (Reptilia, Squamata, Scincidae). Micron, 80:24-33, 2016

Zhang, Y. H.; Li, P. P.; Ma, X.M. \& Xing, L. H. Morphological studies of olfactory and taste organ in Andrias davidianus. J. Shaanxi Norm. Univ., 19(3):46-8, 1991.

Corresponding author:

Chun Yang, Assoc. Prof.

School of Life Sciences

Shanxi Normal University

Linfen

Shanxi Province, 041000

CHINA

E-mail:yangchun774@163.com

Received: 30-09-2019

Accepted: $21-11-2019$ 